\title{
A moderate decrease in temperature inhibits the calcium signaling mechanism(s) of the regulatory volume decrease in chick embryo cardiomyocytes
}

M.M. Souza and R.T. Boyle

\author{
Department of Cell Biology, Duke University Medical Center, Durham, NC, USA
}

\section{Correspondence \\ M.M. Souza \\ Departamento de Ciências \\ Fisiológicas, CCB, UEL \\ Caixa Postal 6001 \\ 86051-990 Londrina, PR \\ Brasil \\ Fax: +55-43-371-4207 \\ E-mail: mmsouza@uel.br}

Presented at the XV Annual Meeting of the Federação de Sociedades de Biologia Experimental, Caxambu, MG, Brazil, August 23-26, 2000

Received April 13, 2000 Accepted September 13, 2000

\section{Abstract}

Chick cardiomyocytes, when submitted to hyposmotic swelling, exhibit a partial regulatory volume decrease (RVD). $\mathrm{A} \mathrm{Ca}^{2+}$ influx by stretch-activated channels signals a taurine efflux and the RVD at $37^{\circ} \mathrm{C}$. We evaluated the cell's performance at room temperature. Cardiomyocytes isolated and cultured from 11-day-old chick embryos were submitted to a hyposmotic solution $\left(180 \mathrm{mOsm} / \mathrm{kg} \mathrm{H}_{2} \mathrm{O}\right)$ at $37^{\circ} \mathrm{C}$ and at room temperature $\left(26^{\circ} \mathrm{C}\right)$. Under these conditions we measured the changes in cell volume as well as the intracellular free $\mathrm{Ca}^{2+}$ (using fura-2). During hyposmotic swelling, cells at $37^{\circ} \mathrm{C}$ displayed a peak relative volume of $1.61 \pm 0.03$ and recovery to $1.22 \pm 0.04(\mathrm{~N}=14)$, while cells at $26^{\circ} \mathrm{C}$ presented a peak swell relative volume of $1.74 \pm$ 0.06 and did not recover $(1.59 \pm 0.09, \mathrm{~N}=9)$. Transient increases in intracellular $\mathrm{Ca}^{2+}$, which are characteristic of the normal RVD, were observed at both temperatures $(29.1 \pm 4.5 \%(\mathrm{~N}=8)$ and $115.2 \pm 42.8 \%$ $(\mathrm{N}=5)$ increase at $37^{\circ}$ and $26^{\circ} \mathrm{C}(\mathrm{P}<0.05)$, respectively). A delay in the $\mathrm{Ca}^{2+}$ transient increase was also observed when the cells were at $26^{\circ} \mathrm{C}$ $\left(109 \pm 34 \mathrm{~s}\right.$ compared to $38 \pm 9 \mathrm{~s}$ at $\left.37^{\circ} \mathrm{C}, \mathrm{P}<0.05\right)$. At room temperature the RVD does not occur because the calcium transient increase, which is an early event in the signaling of the RVD, is delayed. Also, free calcium is not cleared as in the $37^{\circ} \mathrm{C} \mathrm{RVD}$. In the normal RVD the free calcium returns to baseline levels. The very high and persistent free calcium levels seen at room temperature can lead to unregulated enzyme activities and may promote irreversible injury and cell death.
Volume regulatory mechanisms play a critical role in the maintenance of structural integrity, and thus in the proper function of living cells. These regulatory processes involve signal transduction pathways and cellular transport systems.

Cultured chick cardiomyocytes, when
Key words

- Cell volume

- RVD

- Room temperature

- High free calcium 
activated channels which in turn signals a taurine efflux and the RVD at $37^{\circ} \mathrm{C}(2-5)$.

Studies with chick cardiomyocytes under isosmotic conditions at low temperatures reveal a dissipation of the $\mathrm{Na}^{+}$gradient and low levels of $\mathrm{Na}^{+} / \mathrm{K}^{+}$ATPase activity, with the $\mathrm{Na}^{+} / \mathrm{Ca}^{2+}$ exchanger functioning only minimally (6). On the basis of these considerations, we evaluated the RVD under hyposmotic swelling at low temperature.

Cardiomyocytes isolated and cultured from 11-day-old chick embryos (7) were transferred from isosmotic $(290 \mathrm{mOsm} / \mathrm{kg}$ $\mathrm{H}_{2} \mathrm{O}$ ) to a hyposmotic solution $(180 \mathrm{mOsm} /$ $\mathrm{kg} \mathrm{H}_{2} \mathrm{O}$ ) at $37^{\circ} \mathrm{C}$ and at room temperature $\left(26^{\circ} \mathrm{C}\right)$. The cells were perfused at a rate of $\sim 4 \mathrm{ml} / \mathrm{min}$ with HEPES-buffered saline solution $(142.2 \mathrm{mM} \mathrm{NaCl}, 5.4 \mathrm{mM} \mathrm{KCl}, 1.0$ $\mathrm{mM} \mathrm{NaH} \mathrm{PO}_{4}, 10 \mathrm{mM}$ HEPES, $5.6 \mathrm{mM}$ dextrose, $0.8 \mathrm{mM} \mathrm{MgSO}_{4}$, and $1 \mathrm{mM} \mathrm{CaCl}_{2}$; the hyposmotic solution contained $50 \%$ of isosmotic $\mathrm{NaCl}$ ) on the heated (or not) stage

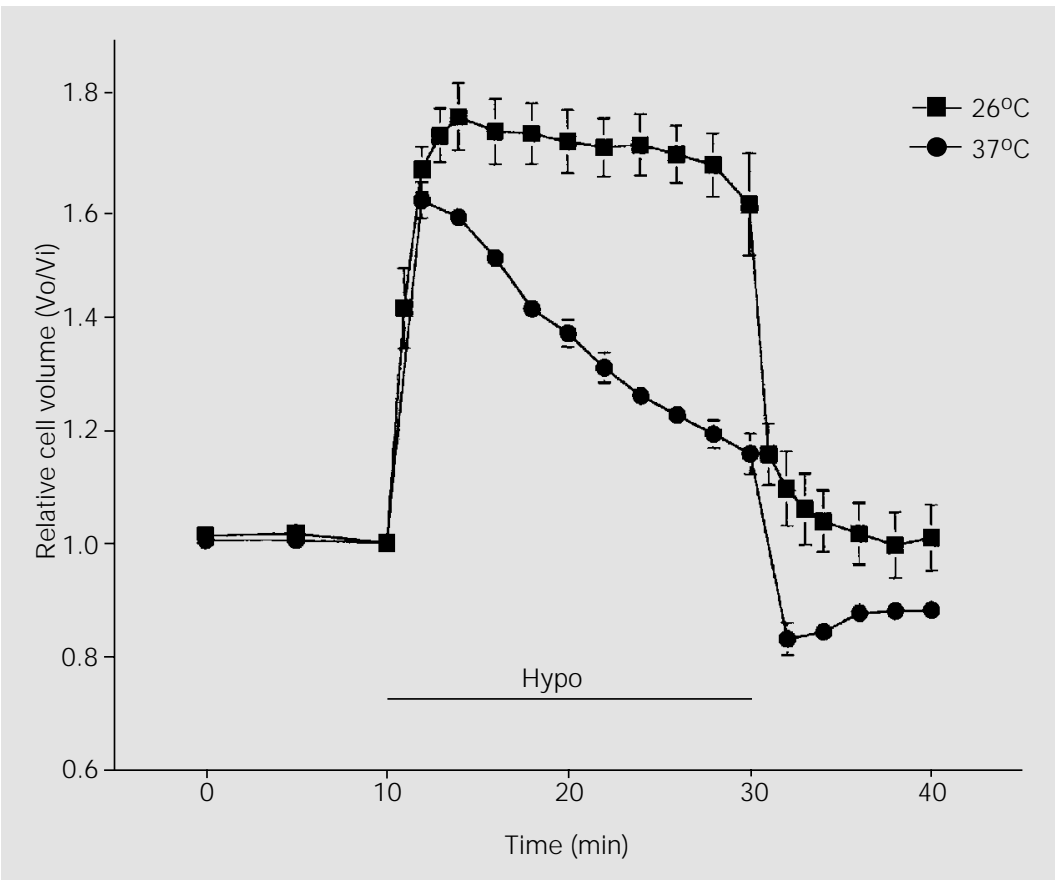

Figure 1 - Cultured chick embryo cardiomyocytes cannot activate volume regulatory processes at room temperature. The cells were exposed to a $180 \mathrm{mOsm} / \mathrm{kg} \mathrm{H}_{2} \mathrm{O}$ hyposmotic stimulus (hypo) at $37^{\circ} \mathrm{C}$ (circles) and $26^{\circ} \mathrm{C}$ (squares). At $26^{\circ} \mathrm{C}$ the myocytes cannot recover to near control volumes as compared to the myocytes at $37^{\circ} \mathrm{C}$. Data are reported as means $\pm \mathrm{SEM}, \mathrm{N}=14$ for $37^{\circ} \mathrm{C}$ and $\mathrm{N}=9$ for $26^{\circ} \mathrm{C}$. Vo: Observed volume; Vi: initial volume. of an inverted microscope (Nikon Diaphot, TMD, Tokyo, Japan). Measurements of cell area from video images of spherical cells (model KP MIL camera, Hitashi Denshi, Ltd.; model PVM-137 monitor, SONY, 1000X resolution) were made using JAVA system software (Jandel Scientific, San Rafael, CA, USA) and were then converted into cell volume. Values were normalized to the last measurement made in the isosmotic solution before volume challenge.

Cells microinjected with fura-2 $(1 \mathrm{mM}$ in $140 \mathrm{mM} \mathrm{KCl}, 10$ mM MOPS-3-[N-morpholino] propane-sulfonic acid and passed through a chelex-100 column, $\mathrm{pH}$ 7.4) were used for intracellular free $\mathrm{Ca}^{2+}$ measurements by the ratiometric method. The excitation and emission wavelengths were $350 / 380$ and $505 \mathrm{~nm}$, respectively. The coverslips were affixed to a heated (or not) stage on a Zeiss IM35 inverted epifluorescence microscope coupled to a Spex model CM3 dual-wavelength excitation spectrofluorometer (Spex Industries, Edison, NJ, USA).

The mean and standard errors were calculated from relative values and plotted on graphs. Data for control and experimental groups were compared by the Student $t$-test.

Single cells, when submitted to a change in osmolality (from 290 to $180 \mathrm{mOsm} / \mathrm{kg}$ $\mathrm{H}_{2} \mathrm{O}$ ) at $37^{\circ} \mathrm{C}$, exhibited a peak swelling of $1.61 \pm 0.03(\mathrm{~N}=14)$ within $2 \mathrm{~min}$, followed by a partial RVD with an end point at $1.22 \pm$ $0.04(\mathrm{~N}=14)$ (Figure 1). However, when the cells were exposed to the same hyposmotic condition, but at $26^{\circ} \mathrm{C}$, the peak of swelling was higher than at $37^{\circ} \mathrm{C}(1.74 \pm 0.06, \mathrm{~N}=9$; $\mathrm{P}<0.05)$ and the relative volume was not recovered $(1.59 \pm 0.09, \mathrm{~N}=9 ; \mathrm{P}>0.05)$ (Figure 1). Also, upon return to isosmotic saline at $30 \mathrm{~min}$, the cells at room temperature returned to pre-swollen levels (relative volume of 1.0), thus further substantiating that no net loss of osmolytes and no RVD results from hyposmotic swelling at $26^{\circ} \mathrm{C}$.

When chick cardiac myocytes are submitted to hyposmotic swelling they exhibit a 
transient increase in intracellular free $\mathrm{Ca}^{2+}$ $(2,3)$, which was also demonstrated in our experiments. The intracellular $\mathrm{Ca}^{2+}$ transient increase (as measured by 350/380) was observed at both temperatures $(29.1 \pm 4.5 \%, \mathrm{~N}$ $=8$, with a delay of $38 \pm 9 \mathrm{~s}$ at $37^{\circ} \mathrm{C}$ ) (Figure 2 ). While at $26^{\circ} \mathrm{C}$ the cells exhibited a $350 /$ 380 fluorescence ratio increase of $115.2 \pm$ $42.8 \%(\mathrm{~N}=5)$ and a delay of $109 \pm 34 \mathrm{~s}$ $(\mathrm{P}<0.05$, when both parameters were compared with the control temperature) (Figure $2)$. Post-experiment calculations were performed to calibrate and transform ratio values to $\mathrm{Ca}^{2+}$ concentrations. Values for the different conditions were approximately: control $(0.16 \mu \mathrm{M})$, hyposmotic solution at $37^{\circ} \mathrm{C}$ $(0.5 \mu \mathrm{M})$ and at $26^{\circ} \mathrm{C}(1.3 \mu \mathrm{M})$.

In order for cells to maintain a constant volume when subjected to anisosmotic environments, they must have the ability to mobilize osmolytes. The RVD response to hyposmotic swelling is usually characterized by a loss of $\mathrm{K}^{+}, \mathrm{Cl}^{-}$and some organic osmolytes (8). In chick cardiac myocytes exposed to a hyposmotic solution, there is a concurrent influx of $\mathrm{Ca}^{2+}(2,3)$ by stretchactivated channels (5), and it has been proposed that protein kinase $\mathrm{C}$, activated by free $\mathrm{Ca}^{2+}$, mediates the amino acid efflux (taurine) that leads to RVD (9). Moreover, it has been shown that cytoskeletal components are involved in the volume regulation of cardiac myocytes. Electrophysiological studies and immunolabeling assays of cytoskeletal proteins reveal suppression of a swelling current and disruption of subplasmalemmal F-actin dynamics induced by cytochalasin B and phalloidin, and the capacity of volume regulation is significantly affected $(10,11)$.

Tissues of mammals exposed to low temperatures show alterations in intracellular ion contents $(6,12)$. For homeotherms, hypothermia can attenuate enzymatic reactions leading to impairment of cell integrity. Considering the differences in temperature dependence for the active and passive transport components of the cell's pump-leak system, which maintains a stable intracellular ion concentration, a change in temperature represents a significant challenge to cellular functions.

Embryonic chick cardiomyocytes in isosmotic solution at low temperatures exhibit an increase in intracellular $\mathrm{Na}^{+}$concentration. It has been suggested that $\mathrm{Na}^{+}$influx from $\mathrm{Na}^{+} / \mathrm{H}^{+}$occurs and may not be corrected by $\mathrm{Na}^{+} / \mathrm{K}^{+}$-ATPase, which in this situation shows only $15 \%$ of its original activity (6). No change was observed in intracellular $\mathrm{K}^{+}$concentration, and total intracellular $\mathrm{Ca}^{2+}$ presented a small increase at low temperature (6), while intracellular free $\mathrm{Ca}^{2+}$ demonstrated a substantial increase (13).

Few reports regarding cell volume regulation at low temperature are available. Malphigian tubules of a New Zealand mountain insect exposed to hyperosmotic conditions at low temperature $\left(0^{\circ} \mathrm{C}\right)$ showed a greater change in cell volume as compared to higher temperatures $\left(20^{\circ} \mathrm{C}\right)$ and no regulatory volume increase was observed (14). Some data about chick cardiac myocytes at low temperatures are available $\left(10^{\circ} \mathrm{C}\right)$, but only under isosmotic conditions, and in this situation the cells shrink (6). The authors believe

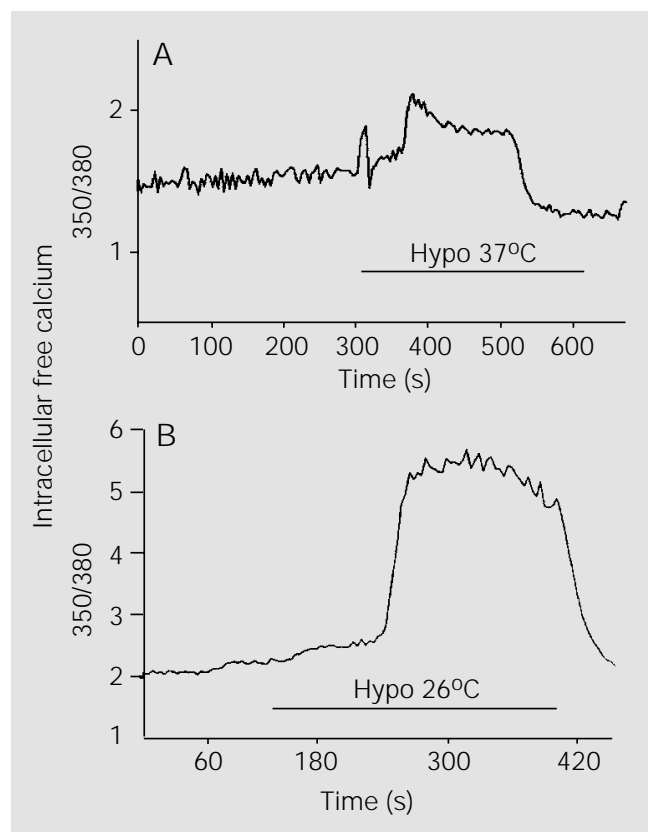

Figure 2 - Intracellular free $\mathrm{Ca}^{2+}$ measurements expressed as fluorescence ratio. Representative experiments showing $\mathrm{Ca}^{2+}$ transient increases in hyposmotic solutions (hypo) at $37^{\circ} \mathrm{C}$ (A) and $26^{\circ} \mathrm{C}(B)$. 
that the shrinkage is a consequence of inhibition of the inwardly directed $\mathrm{Na}^{+} / \mathrm{K}^{+} / 2 \mathrm{Cl}^{-}$ cotransporter.

Our findings reveal that embryonic chick cardiac myocytes during hyposmotic challenge at $26^{\circ} \mathrm{C}$ (room temperature) swell more than at $37^{\circ} \mathrm{C}$, and that at room temperature no RVD is observed. Also, in this situation the intracellular free $\mathrm{Ca}^{2+}$ exhibits a huge increase, much more than a transient increase during hyposmotic swelling at $37^{\circ} \mathrm{C}$.

As mentioned previously, during a hyposmotic challenge there is a $\mathrm{Ca}^{2+}$ influx for signaling the RVD which occurs via stretchactivated channels, and the rapid free $\mathrm{Ca}^{2+}$ transient increase at $37^{\circ} \mathrm{C}$ is a result of $\mathrm{Ca}^{2+}$ influx activating $\mathrm{Ca}^{2+}$ release from intracellular stores (15). At room temperature the transient is also present, but is delayed. Our findings suggest that the $\mathrm{Ca}^{2+}$ release mediated by receptor activities is inefficient at the lower temperature and the same lack of responsiveness may exist with calmodulin, which normally is instrumental in clearing high cytoplasmic free calcium levels through its stimulatory effect on plasma membrane $\mathrm{Ca}^{2+}$ ATPase (16). It is unclear at this point if low temperatures prevent the conformational changes in calmodulin which are necessary to activate $\mathrm{Ca}^{2+}$ ATPase, or if the activated ATPase is less efficient in hydrolyzing ATP at the decreased temperatures. However, the latter is most likely the case and may explain why $\mathrm{Ca}^{2+}$ ATPases in the sarcoplasmic reticulum, which are normally highly efficient in transporting calcium out of the cytoplasm, appear to be inactive at $26^{\circ} \mathrm{C}$. In addition, mitochondrial uptake of $\mathrm{Ca}^{2+}$ through its low-affinity/high-capacity $\mathrm{Ca}^{2+}$ pump appears to be temperature sensitive in our model as this mechanism is known to operate when intracellular free calcium becomes perilously high (17). Also, even with abundant free $\mathrm{Ca}^{2+}$, signal transduction pathways that lead to the activation of protein kinase $\mathrm{C}$ (and thus to the RVD) are also interrupted.

Taken together, the evidence obtained in this study as well as in other investigations on the chick embryo cardiomyocyte suggests that even moderate hypothermia is a potent inhibitor of active transport. This is manifest in the cardiomyocyte inability to mobilize osmolytes for the RVD response and to control and reduce cytoplasmic calcium concentrations to normal levels. It is well known that if the intracellular free $\mathrm{Ca}^{2+}$ concentration rises to high levels, it levies toxic effects on the cells. The very high and persistent free calcium seen at room temperature can lead to unregulated enzyme activities and promote irreversible cell injury and perhaps cell death.

\section{References}

1. Rasmusson RL, Davis DG \& Lieberman M (1993). Amino acid loss during volume regulatory decrease in cultured chick heart cells. American J ournal of Physiology, 264 (Cell Physiology, 33): C136-C145.

2. Smith TW, Rasmusson RL, Freudenrich CC \& Lieberman M (1992). Role of $\mathrm{Ca}^{2+}$ in myocardial volume regulation. Circulation, 86: I-480 (Abstract).

3. Aloi L, Smith J , Moore ES, Swaminathan M \& Lieberman M (1995). Cardiac cell swelling activates a calcium-dependent signal transduction mechanism. FASEB J ournal, 9: A355 (Abstract).

4. Hall SK, Zhang J \& Lieberman M (1997).
An early transient current is associated with hyposmotic swelling and volume regulation in cardiac cells. Experimental Physiology, 82: 43-54.

5. Souza MM, Boyle RT \& Lieberman M (2000). Different physiological mechanisms control isovolumetric regulation and regulatory volume decrease in chick embryo cardiomyocytes. Cell Biology International, 24: (in press).

6. Knerr SMM \& Lieberman M (1993). Ion transport during hypothermia in cultured heart cells: Implications for protection of the immature myocardium. J ournal of Molecular and Cellular Cardiology, 25: 277-
288.

7. J acob R, Lieberman M \& Liu S (1987) Effects of sodium-potassium pump inhibition and low sodium on membrane potential in cultured embryonic chick heart cells. J ournal of Physiology, 387: 549-566.

8. Hoffmann EK \& Dunham PB (1995). Membrane mechanisms and intracellular signaling in cell volume regulation. International Review of Cytology, 161: 172-262.

9. Smith JJ, Spizz G, Aloi L, Moore ES, Dorbandt A, Blackshear PJ \& Lieberman $M$ (1996). Swelling-activated pkC phosphorylation regulates $\left[{ }^{3} \mathrm{H}\right]$ taurine efflux and RVD in chick cardiac myocytes. 
FASEB J ournal, 10: A314 (Abstract).

10. Zhang J, Larsen $\mathrm{TH} \&$ \& Lieberman $M$ (1997). F-actin modulates swelling-activated chloride current in cultured chick cardiac myocytes. American J ournal of Physiology, 273: C1215-C1224.

11. Larsen TH, Dalen H, Boyle RT, Souza MM $\&$ Lieberman M (2000). Cytoskeletal involvement during hyposmotic swelling and volume regulation in cultured chick cardiac myocytes. Histochemistry and Cell Biology, 113: 479-488

12. Sudo J \& Morel J (1984). $\mathrm{Na}^{+}$and $\mathrm{K}^{+}$cell concentration in collagenase treated rat kidney tubules incubated at various temperatures. American J ournal of Physiology, 246: C407-C414.

13. Liu B, Wang LCH \& Belke D (1991). Effect of low temperature on the cytosolic free calcium in rat ventricule myocytes. Cell Calcium, 12: 11-18.

14. Neufeld DS \& Leader J P (1998). Cold inhibition of cell volume regulation during the freezing of insect Malphigian tubules. J ournal of Experimental Biology, 201: 2195-2204.
15. Souza MM, Boyle RT \& Lieberman M (2000). Comparisons of different stages of embryonic development by the physiological regulatory response to hyposmotic challenge. Comparative Biochemistry and Physiology, 125A: 451-458.

16. Head J F (1992). A better grip on calmodulin. Current Biology, 2: 609-611.

17. Carafoli E (1987). Intracellular calcium homeostasis. Annual Review of Biochemistry, 56: 395-433. 